\title{
Choosing a competence based governance role in brownfield redevelopment processes
}

\author{
E. G. J. Blokhuis, W. F. Schaefer, N. van Gogh \& A. J. Kleine \\ Department of Architecture, Building and Planning, \\ Chair Construction Management and Urban Development, \\ Eindhoven University of Technology, the Netherlands
}

\begin{abstract}
The redevelopment of brownfields in the Netherlands stagnates. The fact that the central directing role of municipalities is abandoned is often considered as a cause of the stagnation occurring within these processes. Currently, municipalities can only manage brownfield developments in strategic alliances with different public and private actors. The precise role of municipalities as governor within these alliances is still very indistinct. This paper describes a software model that enables municipalities to determine a suitable governance role in brownfield redevelopment processes. This is realised by distinguishing four types of governance roles and four factors determining the necessity of involving actors in the process. Depending on the presence of these factors in a brownfield redevelopment project, the suitability of the several governance roles can be specified. The method also offers municipalities the possibility of developing their capabilities and related levels of competences based on the predefined governance role they want to practice.
\end{abstract}

Keywords: brownfield redevelopment, municipal governance, roles and competences, stakeholder involvement, process guidance model.

\section{Introduction}

The Dutch government is facing a constantly growing need for redevelopment of ageing brownfields [3]. The arising redevelopment projects are very complex because of the network of economical, political, administrative and legal concerns, physical restrictions and diverging social influences [1]. Current redevelopment projects stagnate because of a lack of insight in the guiding role 
of municipalities [1]. This municipal guiding role has undergone a number of important changes in the previous decades.

The changed positions of market parties and their bigger influence on land exploitation made the exertion of governmental process control increasingly weak [5]. To a great extent municipalities have abandoned their central directing role and are therefore only able to manage redevelopment projects through strategic alliances with different public and private actors each having their own specific interests. The precise role of municipalities as governor within these alliances is still very indistinct.

The research focuses on the determination and development of governance roles and their contributing characteristics related to the ambitions and competencies of the municipalities combined with relevant project and process characteristics. This research resulted in a supportive management method to determine the governance role for municipalities involved in brownfield redevelopments.

\section{Problem elucidation}

In the late nineties, Dutch municipalities could operate fairly autonomous in brownfield development projects, and were able to draw up a plan on the basis of their own insights [4]. Municipalities had several financial instruments at their disposal to secure their position and role, and market parties were mostly not interested in land exploitation because of the market conditions. Because of the changed market conditions, e.g. the bigger influence of market parties on land exploitation, municipal control in these projects decreased.

Brownfields are no longer (re)developed by top down governmental steering [8]. In the growingly complex society, pluricentric network steering - in which several public and private parties play a role - seems more suitable [6]. In current brownfield (re)development processes, the municipality is largely dependent on the behavior and interests of other parties, mostly of landowners and other parties with formal positions in the plan area. The municipality must integrally assess these interests, taking into account the public interest, and integrate the result of this assessment into a plan with a firm social basis [9].

While respecting the responsibilities and relative independence of the parties involved in brownfield redevelopments, the parties usually need stable governance, in which the main direction is monitored, the tempo is raised, the most important decisions are coordinated and the relation with laws and legislation and the public responsibilities are always monitored. Without governance, brownfield redevelopments come to a standstill and implementations gaps or - even worse - contradictions between urban strategy and actual implementation arise [6]. This is the main problem treated in this paper. To prevent the occurrence thereof, municipalities must make a choice regarding their governing role depending on their resources. This has been elaborated in section 3 of this paper. Section 4 describes the development of a decision support model. 


\subsection{Governing brownfield redevelopment processes}

This research handles governance as a particular form of steering: exercising guided influence in a process. Moreover, governance refers to combining separate components into one plan. Thus, governance encloses steering as well as coordinating activities. In this research, we define governance as 'the way in which the municipality gives direction to a brownfield redevelopment, thereby taking into account the interests of all public and private parties involved and the common interest, aimed at guaranteeing a certain result'.

The aim of the municipal governance within brownfield redevelopment projects is to establish cooperation between relevant parties, in order to realize a number of functions and purposes from a public, social importance. The reason to adopt a governance role in a redevelopment project is mostly aimed at controlling a number of aspects. The most important are (1) quality of the project, in relation to other policy fields; (2) relation with the program and the market; (3) financial dimension and feasibility; and (4) time dimension [4].

\section{Assumptions and findings}

The goal of this research is to develop a method that enables municipalities to select the governance role and the related competences in order to successfully guide brownfield redevelopment processes. To reach this goal, several research steps are necessary. These research steps concern roughly the specification of governance roles, relating the governance roles to current cooperation-forms, and specifying the criteria determining these roles. These steps will be treated below.

\subsubsection{Specification of governance roles}

The governance role can be designed in different ways. We distinguish four types of governance roles by means of two variables [7]: (1) Does the governor have perseverance? In other words: can the governor imply his will on other relevant involved parties? (2) Does the governor write his own script or policy, or is the governor dependent on other actors?

Putting these two variables into a matrix (see figure 2) leads to the identification of four types of governance roles: (1) Independent governance role: governor derives his strong position from a high level of perseverance and a low level of dependency on other actors in writing policy; (2) Outsourcing governance role: governor has a high level of perseverance, but is dependent on other actors when writing policy; (3) Co-operating governance role: governor has the privilege to write his own policy, but lacks the required power sources to force other actors to cooperate in executing this policy, whereas the governor is dependent on these actors. In the quest for agreement, the cooperating director is willing to accept compromises on his own policy; and (4) Regulating governance role: governor has a servicing role in the negotiation. Regulating governors are not able to put their policy first, but regulates to partly control the policy of other actors, and to check the proposed policies to the appointed project scope. 


\subsubsection{Relating governance roles to cooperation-forms}

In the Netherlands, five cooperation-forms can be distinguished that are regularly applied in brownfield (re)development projects. Figure 1 represents these five forms on a scale of required interaction. The joint venture has the greatest level of public-private interaction.

- (I) Public development with private execution

- Public-private partnerships, encompassing

- (II) building-claims relationships

- (III) joint venture relationships

- (IV) concession-based relationships

- (V) Private development and execution in accordance with public law

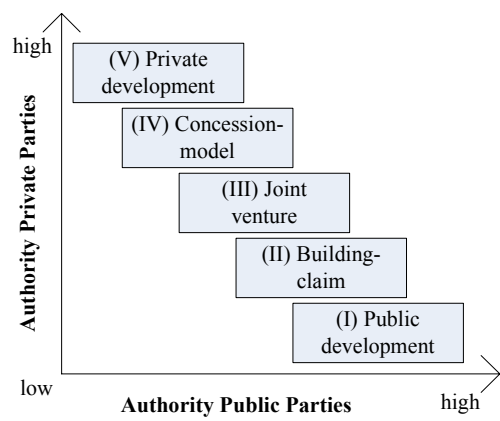

Figure 1: Level of interaction between parties in different cooperationforms

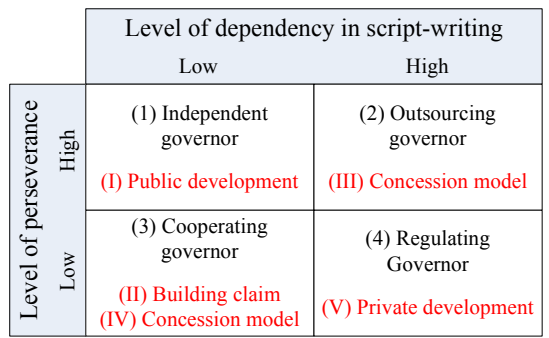

Figure 2: Governance roles related to forms of cooperation.

The above mentioned findings resulted in a matrix showing the relation between the governance roles and current cooperation-forms (see figure 2).

\subsubsection{Criteria determining the appropriateness of governance roles}

The appropriateness of a certain governance role in a given situation is determined by several factors. In this research we limit this to four factors [4]:

- Competencies: internal municipal organization, capacity and quality, harmonization and decision-making, presence of process memory and continuity, knowledge of procedures in public and private law;

- Landownership: municipal ownership, level of fragmentation in the property situation, number of stakeholders;

- Uncertainties and risks: market developments, demographic developments, soil pollution, behavior of residents and other actors, uncertainty concerning the competencies of the municipality and the way in which the project is dependent on these uncertainties;

- Complexity: the scale of the project, the program that must be realized, the number of players.

These factors determine the necessity to involve actors in the governance process related to the positions they possess and the objectives they pursuit. This 
means that the level of knowledge regarding these factors determines the quality of governance according a selected role by the municipality.

\section{Supportive management model}

In this research, the four factors - as mentioned above - determine the necessity of involving actors in the process, and what position they possess. Depending on the presence of these factors and on the mutual relation, the suitability of the several governance roles can be specified. To determine the level of presence of these factors in a brownfield redevelopment project, we conducted literature research, which led to the determination of the most important level qualifying variables per factor. These level qualifying variables formed the basis of the composition a software tool with four questionnaires. A project can be objectively assessed by weighing the several variables in the questionnaires.

\subsubsection{Factor 1: municipal competences and capacity}

The seven aspects are grouped in three areas: internal municipal organisation, knowledge about procedures related to public and private law, as well as municipal capacity. For each aspect a weigh factor is indicated (table 1).

The total qualification score represents the level of municipal competency and capacity. In table 2, an arbitrary partition of the level scores is shown.

The third step is to relate the qualification score to the five possible cooperation-forms to indicate the most suitable role of the municipality regarding this factor. A graphical representation of the total results in a perspective regarding the extent to which the municipality is able to fulfil its role along the scale of possible forms of cooperation is shown in figure 3.

Table 1: Variables composing the level of municipal competence and capacity.

\begin{tabular}{|c|c|c|}
\hline & qualifying variables & Weigh factor \\
\hline & Internal municipal orgar & sation \\
\hline 1 & Internal coordination & $\ldots(0$ to 20$)$ \\
\hline 2 & Decision making & $\ldots(0$ to 20$)$ \\
\hline 3 & Process memory & $\ldots(0$ to 15$)$ \\
\hline 4 & Continuity & $\ldots(0$ to 5$)$ \\
\hline & Knowledge about private and publ & law procedures \\
\hline 5 & Contracts & $\ldots(0$ to 20$)$ \\
\hline 6 & Rules & $\ldots(0$ to 20$)$ \\
\hline & Municipal capacit & \\
\hline 7 & Capacity & $\ldots(-100($ no $)$ or 0$)$ \\
\hline & $\begin{array}{l}\text { I qualification score (sum of weigh factors } \\
\text { I variables) }\end{array}$ & $\cdots$ \\
\hline
\end{tabular}

Table 2: $\quad$ Qualification levels of municipal competency and capacity.

\begin{tabular}{|l|l|l|}
\hline \multicolumn{3}{|l|}{ Qualification table of competency- and capacity-level } \\
\hline- & Low level of competencies / capacity & $<0$ to 33 points \\
\hline$+/-$ & Moderate level of competencies / capacity & 34 to 66 points \\
\hline+ & High level of competencies / capacity & 67 to 100 points \\
\hline
\end{tabular}




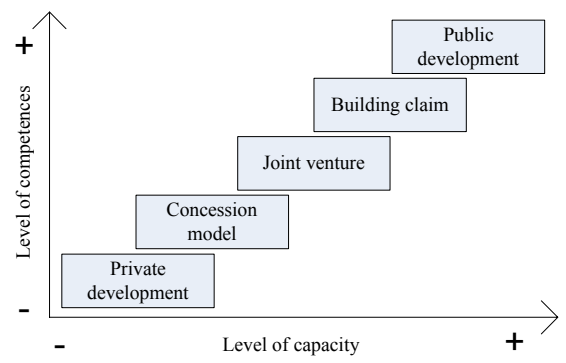

Figure 3: Levels of competencies and capacities related to cooperationforms.

\subsubsection{Factor 2: project risks}

The estimated magnitude of a risk can be estimated by multiplying the expected level of the chance of its occurrence with the level of expected consequences. Table 3 lists twenty-seven important project risks categorized in six groups. Applicants have to validate the risks by attributing a weigh factor to the estimated occurrence and the estimated consequences.

The total qualification score represents the level of project risk magnitude. In table 4, an arbitrary partition of the level scores is showed.

The effectiveness of managing risks within different governance roles is attributed to the relation between an estimated risk level and the level of authority of the governor to influence the chance on occurrence of the risk. The higher his authority, the more likely it is that the effect of his influence will contribute to a reduction of the estimated risk magnitude. The relation between the total estimated risk magnitude and the determined level of authority gives an indication in which cooperation form the governor has the biggest influence on risk reduction. A graphical representation of the total results in a perspective regarding the extent to which the municipality is able to fulfil its role along the scale of possible forms of cooperation is shown in figure 4.

\subsubsection{Factor 3: project complexity}

Complexity of a project is the third factor contributing to dependency on other actors. The questionnaire to validate the level of complexity is described below (table 5).

The total qualification score represents the level of project complexity. In table 6 , an arbitrary partition of the level scores is showed.

The controllability of projects depends not only on the level of complexity but also on the number of parties involved. A graphical representation of the total results in a perspective regarding the extent to which the municipality is able to fulfil its role along the scale of possible cooperation-forms is shown in figure 5 .

\subsubsection{Factor 4: division of landownership}

The factor landownership is the fourth origin that plays a role in the reciprocal dependency of actors. Two variables are presumed to be of high importance: (1) the percentage of public landownership; and (2) the number of private landowners. It is clear that having a high percentage of landownership and a low 
Table 3: $\quad$ Variables composing the level of project risk magnitude.

\begin{tabular}{|c|c|c|c|c|}
\hline \multicolumn{2}{|c|}{ Level qualifying variables } & Occurrence (a) & $\begin{array}{l}\text { Consequence } \\
\text { (b) }\end{array}$ & Magnitude \\
\hline \multicolumn{5}{|c|}{ Risks in the plan area } \\
\hline 1 & Ownerships & $\ldots(1$ to 4$)$ & $\ldots(1$ to 4$)$ & $\ldots(\mathrm{a} * \mathrm{~b})$ \\
\hline 2 & Soil research & $\ldots(1$ to 4$)$ & $\ldots(1$ to 4$)$ & $\ldots(a * b)$ \\
\hline 3 & Buildings & $\ldots(1$ to 4$)$ & $\ldots(1$ to 4$)$ & $\ldots(a * b)$ \\
\hline 4 & Flora en Fauna & $\ldots(1$ to 4$)$ & $\ldots(1$ to 4$)$ & $\ldots(a * b)$ \\
\hline 5 & Existing greenery & $\ldots(1$ to 4$)$ & $\ldots(1$ to 4$)$ & $\ldots(\mathrm{a} * \mathrm{~b})$ \\
\hline 6 & Connection to ext. roads & $\ldots(1$ to 4$)$ & $\ldots(1$ to 4$)$ & $\ldots(\mathrm{a} * \mathrm{~b})$ \\
\hline 7 & Land surveying & $\ldots(1$ to 4$)$ & $\ldots(1$ to 4$)$ & $\ldots(a * b)$ \\
\hline 8 & Image & $\ldots(1$ to 4$)$ & $\ldots(1$ to 4$)$ & $\ldots(\mathrm{a} * \mathrm{~b})$ \\
\hline \multicolumn{5}{|c|}{ Risks in the environment (surroundings) } \\
\hline 9 & Stakeholders & $\ldots(1$ to 4$)$ & $\ldots(1$ to 4$)$ & $\ldots(\mathrm{a} * \mathrm{~b})$ \\
\hline 10 & Positioning & $\ldots(1$ to 4$)$ & $\ldots(1$ to 4$)$ & $\ldots(\mathrm{a} * \mathrm{~b})$ \\
\hline 11 & Environmental aspects & $\ldots(1$ to 4$)$ & $\ldots(1$ to 4$)$ & $\ldots(\mathrm{a} * \mathrm{~b})$ \\
\hline 12 & Infrastructure & $\ldots(1$ to 4$)$ & $\ldots(1$ to 4$)$ & $\ldots(a * b)$ \\
\hline 13 & Surrounding buildings & $\ldots(1$ to 4$)$ & $\ldots(1$ to 4$)$ & $\ldots(\mathrm{a} * \mathrm{~b})$ \\
\hline 14 & $\begin{array}{l}\text { Damage caused by } \\
\text { planning }\end{array}$ & $\ldots(1$ to 4$)$ & $\ldots(1$ to 4$)$ & $\ldots(\mathrm{a} * \mathrm{~b})$ \\
\hline 15 & Business rights & $\ldots(1$ to 4$)$ & $\ldots(1$ to 4$)$ & $\ldots(\mathrm{a} * \mathrm{~b})$ \\
\hline 16 & Accessibility of plan area & $\ldots(1$ to 4$)$ & $\ldots(1$ to 4$)$ & $\ldots(a * b)$ \\
\hline \multicolumn{5}{|c|}{ Risks concerning the organisation } \\
\hline 17 & Actors & $\ldots(1$ to 4$)$ & $\ldots(1$ to 4$)$ & $\ldots(\mathrm{a} * \mathrm{~b})$ \\
\hline 18 & Public parties & $\ldots(1$ to 4$)$ & $\ldots(1$ to 4$)$ & $\ldots(\mathrm{a} * \mathrm{~b})$ \\
\hline 19 & Private parties & $\ldots(1$ to 4$)$ & $\ldots(1$ to 4$)$ & $\ldots(\mathrm{a} * \mathrm{~b})$ \\
\hline 20 & Composition & $\ldots(1$ to 4$)$ & $\ldots(1$ to 4$)$ & $\ldots(a * b)$ \\
\hline \multicolumn{5}{|c|}{ Risks concerning policy } \\
\hline 21 & Policy framework & $\ldots(1$ to 4$)$ & $\ldots(1$ to 4$)$ & $\ldots(\mathrm{a} * \mathrm{~b})$ \\
\hline 22 & Preconditions & $\ldots(1$ to 4$)$ & $\ldots(1$ to 4$)$ & $\ldots(a * b)$ \\
\hline \multicolumn{5}{|c|}{ Financial risks } \\
\hline 23 & Investments & $\ldots(1$ to 4$)$ & $\ldots(1$ to 4$)$ & $\ldots(\mathrm{a} * \mathrm{~b})$ \\
\hline 24 & Financing & $\ldots(1$ to 4$)$ & $\ldots(1$ to 4$)$ & $\ldots(a * b)$ \\
\hline 25 & Exploitation & $\ldots(1$ to 4$)$ & $\ldots(1$ to 4$)$ & $\ldots(a * b)$ \\
\hline \multicolumn{5}{|c|}{ External risks } \\
\hline 26 & Media & $\ldots(1$ to 4$)$ & $\ldots(1$ to 4$)$ & $\ldots(a * b)$ \\
\hline 27 & Market conditions & $\ldots(1$ to 4$)$ & $\ldots(1$ to 4$)$ & $\ldots(a * b)$ \\
\hline \multicolumn{4}{|c|}{ qualification scor } & \\
\hline
\end{tabular}

Table 4: Qualification levels of project risk magnitude.

\begin{tabular}{|l|l|l|}
\hline \multicolumn{3}{|l|}{ Qualification table of level of project risk magnitude } \\
\hline- & Low level of project risk magnitude & 27 to 72 points \\
\hline$+/-$ & Moderate level of project risk magnitude & 73 to 162 points \\
\hline+ & High level of project risk magnitude & 163 to 432 points \\
\hline
\end{tabular}




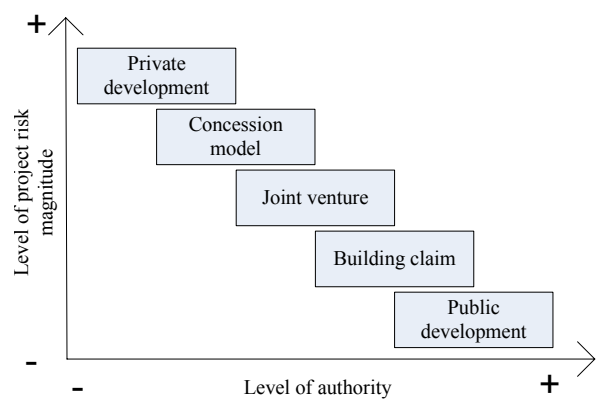

Figure 4: Levels of authority and project risks related to cooperation-forms.

Table 5: $\quad$ Variables composing the level of project complexity.

\begin{tabular}{|c|c|c|}
\hline \multicolumn{2}{|c|}{ Level qualifying variables } & Weigh factor \\
\hline \multicolumn{3}{|c|}{ Decision making } \\
\hline 1 & Actors & $\ldots(0$ to 5$)$ \\
\hline 2 & Interests & $\ldots(0$ to 25$)$ \\
\hline 3 & Dependency & $\ldots(0$ to 10$)$ \\
\hline 4 & Pluriformity & $\ldots(0$ to 10$)$ \\
\hline 5 & Resistance & $\ldots(0$ to 5$)$ \\
\hline \multicolumn{3}{|c|}{ Problem / program } \\
\hline 6 & Junction of functions & $\ldots(0$ to 15$)$ \\
\hline 7 & Mixture of functions & $\ldots(0$ to 10$)$ \\
\hline 8 & Realization & $\ldots(0$ to 10$)$ \\
\hline \multicolumn{3}{|c|}{ Scale } \\
\hline 9 & Dimensions of plan area & $\ldots(0$ to 10$)$ \\
\hline \multicolumn{2}{|r|}{$\begin{array}{l}\text { Total qualification score (sum of weigh factors of all } \\
\text { variables) }\end{array}$} & $\ldots$ \\
\hline
\end{tabular}

Table 6: Qualification levels of project complexity.

\begin{tabular}{|l|l|l|}
\hline \multicolumn{3}{|l|}{ Qualification table of project complexity level } \\
\hline- & Low level of project complexity & 0 to 33 points \\
\hline$+/-$ & Moderate level of project complexity & 34 to 66 points \\
\hline+ & High level of project complexity & 67 to 100 points \\
\hline
\end{tabular}

number of other private landowners stands for a strong municipal position. The graphical representation below (figure 6) shows this relationship and enables the governor to determine his position in the management roles of co-operation.

\subsection{Combining the four questionnaires}

Based on the previous paragraph, table 7 shows an overview of the possible combinations. The five cooperation-forms and corresponding governance roles are represented on the left; the four factors determining the necessity of involving actors in the process are represented above. The marks represent the principles that fit to a certain governance role. 


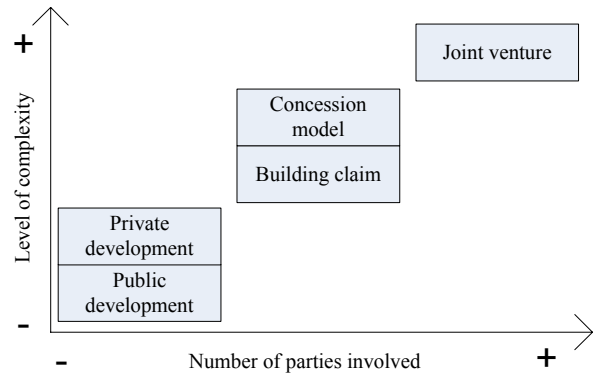

Figure 5: Levels of complexity and number of parties related to cooperationforms.

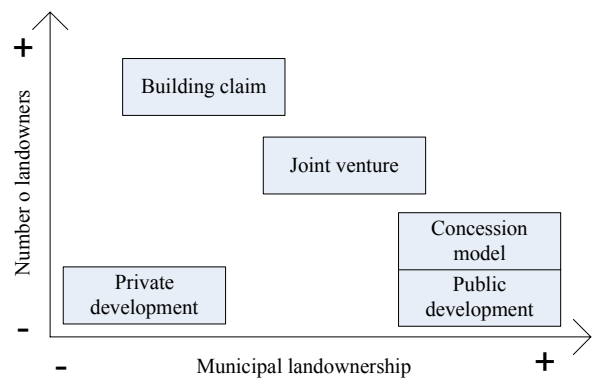

Figure 6: Levels of municipal landownership and percentage of public landowners related to cooperation-forms.

\subsection{Changeability of variables}

The level of changeability of the different factors is assumed to be decisive for the choice of a cooperation-form and thus of a governance role. Factors that cannot be changed are leading in this choice, and easily changeable factors can reinforce the profile of the factor. Changeability of factors is therefore a means to reach up to one of the five cooperation-forms.

Changeability is related to the strengthening of the profile of a factor. When the risk profile is very high and moderately changeable, one can choose for a cooperation-form with a medium risk profile (see figure 7). Because of the moderate level of changeability, the outcome can move 1 box to the left. When a factor can be changed easily, the outcome can move 2 boxes. The degree of changeability of the four factors is determined by the user of the management tool, on the scale (1) not (black), (2) moderately (grey) or (3) easily (white)).

In the example of figure 7, landownership is the leading factor because of the low changeability. Table 7 shows that - with this level of landownership - the cooperation forms 'joint venture' and 'building claim' are suitable. Also, the municipality can choose for a private development. Following on landownership, the risk profile is leading because of its moderate changeability. The cooperation form 'building claim' is not suitable, because of the required low risk level. To implement a joint venture, the municipality has to change the risk level of the 
project. The remaining factors are both easily changeable, and do not change the cooperation-form choice of the municipality. Depending on the preferred position, the municipality chooses between regulating in a private development or cooperating in a joint venture. As regulating governor, the municipality bears relatively low risks, but the authority decreases. The municipality should state clear rules in this situation, and has to monitor whether the rules are complied. As cooperating governor, the municipality bears more risks, but is better able to control the contents of the brownfield redevelopment. However, the municipality should extend her level of competences and lower the risk profile of the project when choosing to cooperate.

Table 7: Overview of governance roles with suiting profiles of the four factors.

\begin{tabular}{|c|c|c|c|c|c|c|c|c|c|c|c|c|c|}
\hline & \multicolumn{3}{|c|}{$\begin{array}{c}\text { Capacity / } \\
\text { competence }\end{array}$} & \multicolumn{3}{|c|}{ Risks } & \multicolumn{3}{|c|}{ Complexity } & \multicolumn{3}{|c|}{$\begin{array}{c}\text { Land- } \\
\text { ownership }\end{array}$} \\
\hline & & - & +1 & + & - & $\begin{array}{ll}+1 \\
-\end{array}$ & + & - & $\begin{array}{l}+1 \\
-\end{array}$ & + & - & +1 & + \\
\hline \multicolumn{14}{|c|}{$\begin{array}{c}\text { Independent governor / } \\
\text { public development }\end{array}$} \\
\hline \multirow{3}{*}{ 芯 } & $\begin{array}{c}\text { Cooperating } \\
\text { governor / building } \\
\text { claim }\end{array}$ & & & & & & & & & & & & \\
\hline & $\begin{array}{l}\text { Cooperating } \\
\text { governor / joint } \\
\text { venture }\end{array}$ & & & & & & & & & & & & \\
\hline & $\begin{array}{c}\text { Outsourcing } \\
\text { governor / } \\
\text { concession model }\end{array}$ & & & & & & & & & & & & \\
\hline & $\begin{array}{l}\text { egulating governor / } \\
\text { rivate development }\end{array}$ & & & & & & & & & & & & \\
\hline
\end{tabular}

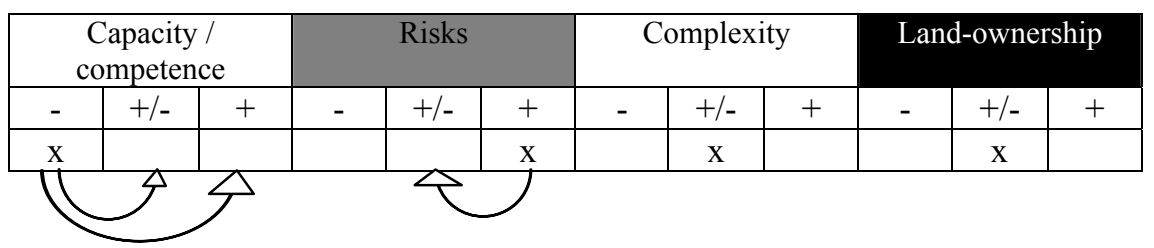

Figure 7: Example of changeability of factors.

\section{Validation of the research results}

The validation of the findings, their interpretation and the ways they are combined are validated by an expert panel (see [2]). The method designed was also validated. Moreover, the method was successfully applied to two cases. Minor adaptations were implemented as a result of the validations. These were mostly related to interpretation of terms. 


\section{Conclusions}

The first conclusions concern scientific relevance of our research. To get a grip on the changing role of municipalities in brownfield redevelopment processes, we distinguished four governance roles: (1) independent governor; (2) outsourcing governor; (3) cooperating governor; and (4) regulating governor. Furthermore, we distinguish four factors - competence / capacity, risks, complexity and landownership - determining the necessity of involving actors in the process. Depending on the presence of these factors and on the mutual relation, the suitability of the several governance roles can be specified.

Secondly, to cover societal relevance, we developed a supportive management software tool enabling municipalities to determine a suiting governance role in the process of redevelopment of brownfields. The other way around a municipality could fully develop a preferred governance role by improving its performances to the levels as mentioned in the different sections of this supportive management method.

\section{References}

[1] Blokhuis and Schaefer (2007) A sustainable approach for industrial area redevelopment in the Netherlands - printed in: Sustainable Development and Planning III, Vol. 1. (pp. 81-93) ISBN 978-1-84564-069-9. WIT Press.

[2] Gogh, N. van (2005) In de greep van gebiedsontwikkeling, beslisondersteunend instrument voor de invulling van de gemeentelijke regierol bij binnenstedelijke herontwikkeling - graduation report, Eindhoven University of Technology, chair Construction Management.

[3] Graaf, R.S. de (2005) Strategic Urban Planning - industrial area development in the Netherlands, to direct or to interact? Thesis, University of Twente, Enschede.

[4] Korthals Altes, W. et al. (2004) Organisatie van prestatie, regie in de stedelijke ontwikkeling - VNG - Den Haag.

[5] Louw, E. (2000) The production of business sites in the Netherlands - in: Tijdschrift voor Economische en Sociale Geografie, vol 91, nr. 1, pp 85-91.

[6] Priemus, H. (2006) Stedelijke strategieën en stedelijke regie - In s.n. (Ed.), Strategieën voor stedelijke vernieuwing (pp. 1-8). Eindhoven University of Technology.

[7] Pröpper, I. et al. (2004) Lokale regie uit macht of onmacht? Onderzoek naar de optimalisering van de gemeentelijke regiefunctie - Report under authority of the Dutch Ministry of Internal Affairs - Vught, the Netherlands.

[8] Valk, A. van der (2002) The Dutch planning experience - in: Landscape and Urban Planning 58 (201-210) - Elsevier Science - London.

[9] Whitman, I.L. (2006) Brownfield redevelopment by the private sector: market driven decision making - paper presented at conference Brownfields III, Prevention, Assessment, Rehabilitation and Development of Brownfield Sites - WIT Conference - Tallinn, Estonia. 